Journal of Science Education Research

Journal homepage: www.journal.uny.ac.id/jser

JSER

\title{
GROWING ENVIRONMENTAL LITERACY TOWARDS ADIWIYATA SCHOOLS THROUGH NATURAL SCIENCE LEARNING BASED ON PEDAGOGY FOR SUSTAINABILITY
}

\author{
Susilowati, Insih Wilujeng, and Purwanti Widhy Hastuti \\ Natural Science Education, Yogyakarta State University, Jl. Colombo No. 1, Yogyakarta 40132, Indonesia \\ Corresponding Author. Email: susilowati@uny.ac.id
}

\begin{tabular}{|c|c|}
\hline & ABSTRACT \\
\hline $\begin{array}{l}\text { Keywords: } \\
\text { environmental } \\
\text { literacy, } \\
\text { Adiwiyata } \\
\text { schools, } \\
\text { pedagogy for } \\
\text { sustainability }\end{array}$ & $\begin{array}{l}\text { Environmental awareness is an issue that continues to evolve with the development } \\
\text { of science and technology. Various problems that arise include attitudes to protect } \\
\text { the environment, to choose a healthy lifestyle, to utilize natural resources, to deal } \\
\text { with natural disasters, and to concern about the rising global temperatures. The } \\
\text { government carries out the Adiwiyata school program with the aim to instill values } \\
\text { of environmental awareness for students. This leads to the importance of building } \\
\text { environmental literacy to direct in building the environmentally-aware attitude that } \\
\text { supports the preparation to become Adiwiyata schools. Learning based on } \\
\text { sustainability (pedagogy for sustainability) has the potential to be integrated in } \\
\text { science learning, considering that natural science subjects examine natural } \\
\text { phenomena and the symptoms physically, chemically, and biologically as well as } \\
\text { the relation to technology, environment, and society. Attitudes and actions towards } \\
\text { environmental literacy can be inculcated through the development of learning } \\
\text { processes containing pedagogy for sustainability that emphasizes activities to seek, } \\
\text { explore, discuss, and investigate information and also to plan actions that are } \\
\text { beneficial to the environment and do not carry any negative impacts on future } \\
\text { generations. }\end{array}$ \\
\hline
\end{tabular}

C2018 JSER. Yogyakarta State University

\section{INTRODUCTION}

Environmental awareness is an issue that continues to evolve with the development of science and technology. Various problems that arise include attitudes to protect the environment, to choose a healthy lifestyle, to utilize natural resources, to deal with natural disasters, and to concern about the rising global temperatures. There is urgency to develop and grow environmentally-aware attitude in learning. One effort to shape this attitude among students is through the implementation of the Adiwiyata program through formal education at all levels of schools. Some schools have obtained Adiwiyata school label.
The government conducts Adiwiyata school program with the aim of instilling the value of environmental awareness among students. This program is carried out by the Department of Environment and the Directorate General of Primary and Secondary Education of the Ministry of Education and Culture and is intended to develop a culture of environmental awareness. Adiwiyata schools are schools that have implemented a system with the intention of realizing school entities responsible for environmental protection and management efforts through good school governance to support sustainable development.

In fact, the existence of the Adiwiyata program has not been able to guarantee full improvement in environmental awareness among 
students. Based on the research conducted by Landriany (2014), Adiwiyata has not been successfully implemented in several cities. This is due to several factors. For example, some students still do not understand the concept of eco-schools (Adiwiyata schools). Some of them still do not care about environmental conditions. There is also lack of community participation and enthusiasm for the implementation of Environmental Education (PLH) among teachers and school staffs (Rizky Dewi Iswari and Suyud W Utomo, 2017: 36). Thus, the understanding of environmental literacy in which the environmentally-aware attitude is shaped to prepare for Adiwiyata schools is urgently required. Education plays an important role in changing the behavior of students to produce comprehensive learning outcomes in terms of both cognitive and psychomotor aspects and attitude. Attitude is a substantive factor in driving positive human behavior. The awareness of the sustainability of the environment and natural resources becomes an urgent matter at this time.

Education that leads to the sustainability of resources and the environment certainly needs to be integrated in natural science subjects. Sustainability-based learning has the potential to be integrated into natural science, considering that natural sciences examine natural phenomena and the symptoms physically, chemically, and biologically as well as the relation to technology, environment, and society. This is in accordance with the nature of natural sciences which reflects holistic issues in real life. Natural Sciences (Sciences) can be studied from several aspects, namely as a body of knowledge, a way of thinking, a way of investigation and the relation to technology and society. To be able to act and aware about the environment, students need to have competence in identifying environmental issues, analyzing environmental issues, evaluating problem solving, and designing and determining actions. Some of these abilities are aspects of the quality of environmental literacy of students.

The environmentally-aware attitude and character is formed through a thinking process where students are invited to analyze issues and determine actions against the issues. This process will support the achievement of one's sensitivity to the environment. The environmentally-aware attitude is as an internalization of actions becoming a habit in thinking and taking actions towards an issue. To shape the abilities and attitude, a suitable pedagogy (teaching method) is needed, namely pedagogy for sustainability. According to Erin Redman (2013: 6), pedagogy for sustainability develops system thinking, foresight thinking, group collaboration in solving problems, and action orientation to act accordingly. This model can be done by problem solving learning, real world learning, and experimental learning.

Those types of learning can develop outcomes in the form of changes in individual behavior towards environmental issues. The ability to determine a learning strategy is one of the standards that science teachers must master. Science teachers must master the standards as stated in NSTA (National Science Teacher Association). NSTA (2003: 1) recommends Standards for Science Teacher Preparation. The standards contain content, nature of science, inquiry, issues, general skills of teaching, curriculum, science in the community, assessment, safety and welfare, and professional growth. They are consistent with the vision of NSES (National Science Education Standards). NSTA (2003: 8) also recommends that elementary and secondary science teachers must have science interdisciplinary skills. That is why developing integrated science learning becomes urgency.

\section{METHOD}

This research employed library research collecting various sources to explore learning that fosters environmental literacy. The sources included books and journals

\section{RESULT}

\section{A. Pedagogy for Sustainability}

1. The Definitions of Sustainable Development

Brundtland (1987, in Holbrook, 2009: 47) describes sustainable development as the following: "Sustainable development is development that meets the needs of the present without compromising the ability of future generation to meet their own needs." It means sustainable development is suitable for current human needs without having to reduce the needs of future generations. This also means that the implementation of development at this time should consider whether it harms future generations (Paul Suparno, 2012: 8).

John McMurtry (2001, in Holbrook, 2009: 47), a philosopher, explains that sustainable development is related to the development of civil commons, general needs, where everyone in society can access the necessities of life so that everyone can develop and express themselves as human beings. General needs include general education, health, environmental legality, health and safety rules, and public broadcasts (Paul Suparno, 2012: 9).

Sustainable development has 3 important perspectives. They are socio-cultural, 
environmental, and economic perspectives (UNESCO, in Puslitjak, 2010: 12):

a. Socio-cultural perspective is an understanding of social institutions and the role of humans in change and development.

b. Environmental perspective is an awareness of natural resources, physical environment, the impact of human activities, and decision making related to the commitment to create social and economic development policies.

c. The economic perspective is sensitivity to the limitations and potential of economic growth and its impact on society and the environment.

\section{Sustainability Competence}

According to Erin Redman (2013: 4), "Competence refers to the concept and skills that enable students to understand and resolve complex sustainability problem and task." This means that competence is a concept and skill where students can understand and solve problems about sustainability and tasks related to these problems. There are four competencies in sustainability as stated by Erin Redman (2013: 4-5), namely (1) system thinking and understanding of interconnectedness, (2) long term, foresighted reasoning, and strategizing, (3) stakeholder engagement and group collaboration, (4) action orientation and change-agent skills. It can be summarized that from the system thinking, students are expected to have applicative competence in thinking, and being aware of the effects, reducing the effects. The system thinking not only discusses the effects but also finds out the interconnectedness that occurs in households, classes, and schools. After the process of thinking about effects, the next competency is to predict and think about the future as well as to plan and form the strategy. This stage emphasizes that the actions taken at this time have consequences for the future in the long term. The third competency is the ability to influence and make agreements in groups. To realize sustainability, collaboration is needed. Students need to be facilitated with skills and resources to participate in collaborative decision making for past, present, and future conditions. Students can be assigned to interview the family and industry environment about an issue. The last competency is actions that lead to changes in behavior of both individuals and groups. Facilitating students to use their skills and self-confidence to take action for the sustainability of the future is a substantive matter.

\section{Pedagogy for Sustainability Model}

Pedagogy is a way of teaching to integrate sustainability competence. According to Erin Redman (2013: 6), methods that can be focused are real world learning, critical problem solving and experiential (active) learning. The following is a pedagogical model for achieving sustainability competence:

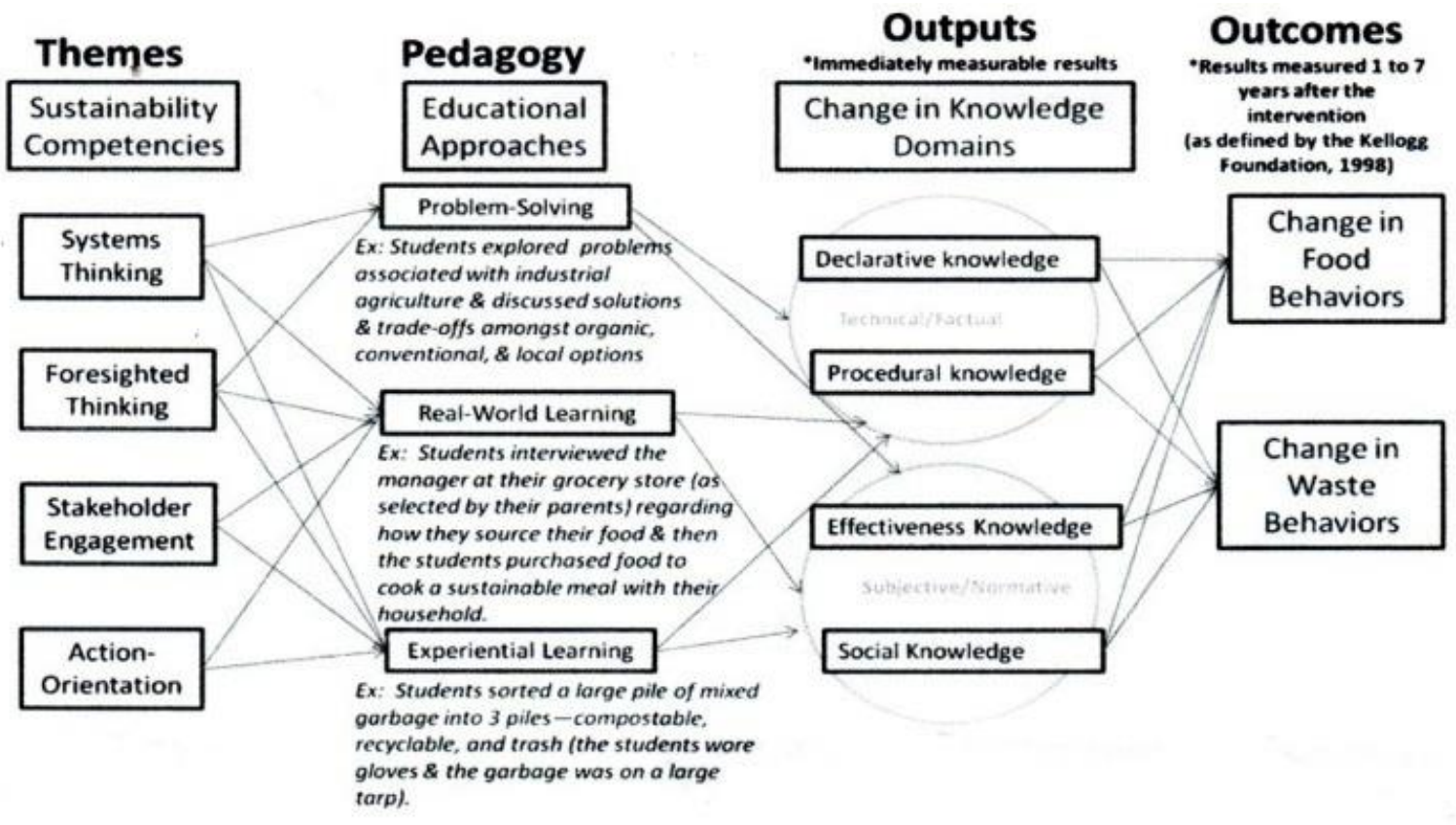

Figure 1. Approach for Targeting Behavior Change Outcomes 


\section{CONCLUSION}

Environmentally-aware attitude is part of environmental literacy. Environmental literacy will support the preparation towards Adiwiyata schools. It can be grown through science learning that is oriented towards pedagogy for sustainability. Learning components that lead to sustainability include system thinking, foresight thinking, group collaboration in solving problems, and action orientation to act accordingly.

\section{REFERENCES}

Borg, W. R. And Gall, M. D. 1983. Educational Research An Introduction 4th Ed. New York: Longman, Inc.

Burchett, Julianna H.. 2015. Enviromental Literacy And Its Implications for Effective Public Policy Formation. The University of Tennesse, Knoxville. Center for Public Policy

Chiapetta, Eugene L. \& Koballa, Thomas R. 2010. Science Instruction in the Middle and Secondary Schools. NewYork: Pearson.

Erdogan, Zdravka , Narcinkowski. 2009. Components of Enviromenta Literacy in elementary. Journal of Mathematic, Science and Tecnology education. 5 (1),5-26

Ela Nurhayati. Implementasi Kurikulum Berbasis Lingkungan di Sekolah Adiwiyata. Jurnal Manajemen Pendidikan. FIP UNESA

Hewitt, Paul G \& etc. 2007. Conceptual Integrated Science. Pearson Education: US.

Hollweg, K. S., Taylor, J. R., Bybee, R. W., Marcinkowski, T. J., McBeth, W. C., \& Zoido, P. 2011. Developing a Framework for Assessing Environmental Literacy. Washington, DC: North American Association for Environmental Education.

Insih wilujeng. 2012. Redesain Kurikulum S1 Pendidikan IPA Menuju Standards for Secondary Science Teacher Preparation. ISPI National Seminar Article

I Wayan Dasna. 2012. Peran dan Tantangan Pendidikan MIPA dalam Menunjang Arah Menuju Pembangunan Berkelanjutan. FMIPA UNDIKSHA National Seminar Prosiding
Meltzer, David E. 2002. The relationship between mathematics preparation and conceptual learning gains in physics: A possible "hidden variable" in diagnostic pretest scores. Department of Physics and Astronomy, Iowa State University. Accessed on January 9, 2013. Retrieved from: http://www.physicseducation.net/docs/AJPDec-2002-Vol.7012591268.pdf.

McBeth, William \& Volk, Trudi L. 2010. The National Environmental Literacy Project: A Baseline Study of Middle Grade Students in the United States. The Journal of Enviromental Education, 41(1), 55-67. Southern Illinois University: USA.

Hollweg, K. S., Taylor, J. R., Bybee, R. W., Marcinkowski, T. J., McBeth, W. C., \& Zoido, P. 2011. Developing a framework for assessing environmental literacy. Washington, DC: North American Association for Environmental Education. Available at http://www.naaee.net.

NSTA. 2003. Standards for Science Teacher Preparation. Revised 2003.

Paul Suparno. 2012. Peningkatan Mutu Pendidikan MIPA untuk Menunjang Pembangunan Berkelanjutan (Sustainable Development). FMIPA UNDIKSHA National Seminar Prosiding.

Redman, Erin. 2013. Advancing educational pedagogy for Sustainability: Developing andimplementing programs to transform behavior. International Journal of Enviromental \& Science Education, Vol.8, No. 1, January 2013, 1-34.

Rizky Devi Iswari \& Suyud W Utomo. 2017. Evaluasi Penerapan Program Adiwiyata untuk Membentuk Perilaku Peduli Lingkungan di Kalangan Siswa. Jurnal Ilmu Lingkungan. Volume 15. Program Studi Ilmu Lingkungan Sekolah Pascasarjana UNDIP.

Sund \& Trowbridge. 1967. Teaching Science by Inquiry in the Secondary School. Ohio:Charles E. Merrill Publishing Company.

Trefil, James \& Hazen Robert. 2007. The Sciences, An Integrated Approach. USA: John Wiley and Sons, Inc. 